\title{
Influence of storage temperature on infectious hematopoietic necrosis virus detection by cell culture isolation and RT-PCR methods
}

\author{
Peter Hostnik*, Darja Barlič-Maganja, Marjeta Štrancar, Vlasta Jenčič, \\ Ivan Toplak, Jože Grom
}

University of Ljubljana, Veterinary Faculty, Institute of Microbiology and Parasitology, Virology Unit, Gerbičeva 60, 1115 Ljubljana, Slovenia

\begin{abstract}
The detection of infectious hematopoietic necrosis virus (IHNV) in infected rainbow trout Oncorhynchus mykiss and in cell culture supernatants stored under different conditions was studied. IHNV-positive fish visceral organ homogenates and cell culture supernatants were incubated at 4 and $25^{\circ} \mathrm{C}$. Virus titre was measured by virus isolation on epithelioma papulosum cyprini (EPC) cells and the IHNV RNA was detected by RT-PCR and semi-nested RT-PCR. The influence of repeated freezing and thawing on the virus isolation from organ homogenates and from cell culture supernatants was studied as well. It was possible to isolate the virus from IHNV-positive organ material during the $3 \mathrm{~d}$ of incubation at $4{ }^{\circ} \mathrm{C}$ but, only on the first day of incubation at $25^{\circ} \mathrm{C}$. Viral RNA could be amplified during the incubation period of $35 \mathrm{~d}$ at $4^{\circ} \mathrm{C}$ but only during $8 \mathrm{~d}$ of incubation at $25^{\circ} \mathrm{C}$. In IHNV-infected cell culture supernatant stored at $4^{\circ} \mathrm{C}$, it was possible to detect virus for 36 and $16 \mathrm{~d}$ in supernatant stored at $25^{\circ} \mathrm{C}$. Viral RNA could be followed by using molecular methods during the entire experimental period of $123 \mathrm{~d}$. Each cycle of freezing and thawing of samples resulted in a reduction of IHNV titre in the suspension of visceral organs, while the virus titre in cell culture supernatant remained almost the same following 33 freezing-thawing cycles. The present results show that rapid laboratory processing and storage of potentially virus-containing tissue samples as well as the use of different detection methods are very important for efficient IHNV diagnosis.
\end{abstract}

KEY WORDS: Infectious hematopoietic necrosis virus · IHNV · Diagnosis · Virus isolation · RT-PCR · Storage

Resale or republication not permitted without written consent of the publisher

\section{INTRODUCTION}

Infectious hematopoietic necrosis virus (IHNV) produces systemic infections with high mortality in rainbow trout Oncorhynchus mykiss and also in other economically important salmonid species including brown trout Salmo trutta fario, Atlantic salmon Salmo salar and Pacific salmon Oncorhynchus sp. This virus is responsible for increasingly devastating losses of young fish. In hatcheries where the disease breaks out for the first time, total mortality can reach up to $80 \%$.

*Email: peter.hostnik@vf.uni-lj.si
IHNV was first isolated in western North America and then spread to Japan and Europe. It was first detected in 1987 in Italy (Bovo et al. 1987) and France (Baudin-Laurencin 1987). In the summer of 1997, IHNV was also isolated for the first time from rainbow trout in Slovenia. The results of monitoring ovarian and seminal fluids annually have shown that many fish farms have become infected with IHNV (Jenčič \& Hostnik 1998).

IHNV belongs to the new genus Novirhabdovirus of the family Rhabdoviridae (Walker et al. 2000). Its genome consists of a linear molecule of negative sense, non-segmented, single-stranded RNA, encoding 5 genes for structural proteins and 1 gene for a non-virion protein (Kurath \& Leong 1985, Kurath et al. 1985). 
An IHNV infection is often diagnosed on the basis of epidemiological and clinical findings; however, laboratory diagnosis of IHNV can lead to better control methods. The most commonly used test for IHNV detection is the virus isolation test using epithelioma papulosum cyprini (EPC) and BF-2 cell lines (Lorenzen et al. 1999). The identification of virus isolates may be performed by the indirect fluorescent or peroxidase antibody test, which detects virus antigen directly in cell cultures using monoclonal anti-IHNV antibodies and antimouse conjugate as the next step. Another confirmatory test for IHNV identification is the virus neutralization test on tissue culture cells (Lorenzen et al. 1999). These methods are labor intensive and time-consuming (requiring about 5 to $20 \mathrm{~d}$ ); samples for the diagnosis must be stored under optimal conditions in order to obtain valid results. The inactivation of IHNV during sampling, transport and manipulation in laboratories is possible and could negatively influence the virus isolation test.

For the confirmation of IHNV infection in fish samples the immunofluorescent antibody test (IFAT) has been extensively used for the detection of viral antigens in cell cultures and fish tissues (reviewed in Sanz $\&$ Coll 1992). Other tests employed in routine diagnostics include immuno-capture of viral ribonucleocapsid proteins by ELISA. The ELISA test using polyclonal antibodies, as well as monoclonal antibodies against the $\mathrm{G}$ or the N proteins, has been introduced for IHNV diagnosis (Dixon \& Hill 1984, Ristow \& Arnzen 1989, 1991). Some monoclonal antibodies were found to have lower sensitivity for detecting some IHNV isolates. Monoclonal antibodies specific to the G-protein had cross-reactivity with viral haemorhagic septicaemia virus (VHSV) (Enzmann et al. 1991).

In recent years molecular methods have also been developed and applied to IHNV diagnostics. A reverse transcriptase-polymerase chain reaction (RT-PCR) method which detects specific parts of the IHNV genome has been described (Brushhof et al. 1995, Arakawa et al. 1990, Alonso et al. 1999, Miller et al. 1998, Barlič-Maganja et al. 2002). These methods have been shown to be more sensitive and faster than current procedures.

The aquatic rhabdovirus group, including IHNV, represents viruses which are not stable at room temperature. For example, IHNV in cell culture supernatant was completely inactivated within $8 \mathrm{~h}$ at $32^{\circ} \mathrm{C}$, and after $7 \mathrm{~d}$ at $27^{\circ} \mathrm{C}$ (Pietsch et al. 1977). It has also been reported that IHNV was inactivated within $140 \mathrm{~min}$ at $38^{\circ} \mathrm{C}$ and within $24 \mathrm{~h}$ at $32^{\circ} \mathrm{C}$. A reduction of IHNV titre was not observed within $5 \mathrm{~h}$ at $22^{\circ} \mathrm{C}$ in cell culture medium; however, the titre in visceral organ suspension decreased more rapidly (Gosting \& Gould 1981). For short-term storage, $4^{\circ} \mathrm{C}$ was generally the most efficient temperature for preserving infectious virus in ovarian fluids, sera and homogenates of different fish tissues, while for longer periods (up to 1 yr) the infectivity was most efficiently preserved by storage at $-20^{\circ} \mathrm{C}$ (Burke \& Mulcahy 1983).

In the present study the effect of different storage conditions on the detection of IHNV by virus isolation and molecular methods was tested. A suspension of IHNV-positive visceral organs as well as IHNV-inoculated cell culture fluid supernatants were stored at 4 and $25^{\circ} \mathrm{C}$, respectively, and virus was detected using the cell culture isolation method, RT-PCR and seminested RT-PCR. The effects of freezing and thawing of similar samples were also examined.

\section{MATERIALS AND METHODS}

Sample preparation. Rainbow trout from 7 to $9 \mathrm{~cm}$ in length were collected from a fish farm with a recent history of IHNV. Visceral organs (kidney, spleen, heart) from 10 fish were pooled and used in the present study. Reference strain IHNV 4008, kindly provided by Dr. Bovo (Istituto Zooprofilattico Sperimentale, Padova, Italy), was also included in the experiment as a positive control.

Tissue material was homogenised and diluted 1:10 with cell culture medium (minimal essential medium [MEM], Gibco BRL) containing 10\% foetal bovine serum (Svanoclone FBS) and antibiotic Garamycin (Lek d.d.). Specimens were centrifuged at $2500 \times g$ for $15 \mathrm{~min}$ at $4^{\circ} \mathrm{C}$ and the obtained supernatant fluids were divided into 2 equal parts (Sample A and Sample B). Sample A was again divided into 2 tubes (Sample A1 and Sample A2). The tube with Sample A1 was stored at $4^{\circ} \mathrm{C}$ and the tube with Sample A2 was stored at $25^{\circ} \mathrm{C}$. Both samples were kept under these conditions for 54 d. Sample B was filter sterilised (Minisart, $0.20 \mu \mathrm{m})$ and inoculated on a monolayer of EPC cells. After $5 \mathrm{~d}$ of incubation at $15^{\circ} \mathrm{C}$, culture medium was collected and centrifuged at $2500 \times g$ for $15 \mathrm{~min}$ at $4^{\circ} \mathrm{C}$. The supernatant fluid was divided into 2 equal parts (Sample B1 and Sample B2). Sample B1 was stored at $4^{\circ} \mathrm{C}$ and Sample B2 was stored at $25^{\circ} \mathrm{C}$. Both samples were kept under these conditions for $123 \mathrm{~d}$.

The persistence of IHNV under different storage conditions was examined by virus isolation, RT-PCR and semi-nested RT-PCR method.

To study the influence of freezing and thawing on the suitability of samples for virus diagnostics, a part of a homogenised IHNV-positive pool of fish visceral organs and the IHNV-infected EPC cell culture fluid were frozen at $-70^{\circ} \mathrm{C}$. The frozen samples were thawed in cold water. The freezing-thawing procedure was repeated 33 times. After each thawing, the sam- 
ples were diluted in MEM (1:10) and centrifuged at $2500 \times g$ for $15 \mathrm{~min}$ at $4^{\circ} \mathrm{C}$. Supernatants were filter sterilised through a $0.20 \mu \mathrm{m}$ filter and virus titration on EPC cells was performed. In parallel, RT-PCR and semi-nested PCR were done for virus RNA detection in each sample.

Virus isolation and immunofluorescent detection. Sample B was inoculated onto confluent EPC cells in 96 -well microplates. Ten-fold dilutions from $10^{0}$ to $10^{-7}$ were prepared in mock plates (the $180 \mu \mathrm{l}$ cell culture medium and $20 \mu \mathrm{l}$ sample) and inoculated, using $50 \mu \mathrm{l}$ per well. After adsorption for $30 \mathrm{~min}$ at $15^{\circ} \mathrm{C}, 50 \mu \mathrm{l}$ of cell culture medium supplemented with $10 \%$ FBS were added and plates were incubated at $15^{\circ} \mathrm{C}$. After $6 \mathrm{~d}$ of incubation, the cell culture medium was removed and cells were fixed with $85 \%$ acetone at $-20^{\circ} \mathrm{C}$. The detection of IHNV by an IFAT was carried out with monoclonal antibodies (BioX) following the protocol recommended by the supplier. Briefly, monoclonal antibodies were diluted 1:40 in PBS-T (0.01 M phosphate buffered saline plus $0.05 \%$ [v/v] Tween 20) and added on air-dried cell monolayer in 96-well microplates. After $1 \mathrm{~h}$ incubation period at $37^{\circ} \mathrm{C}$, the cells were rinsed with PBS-T and rabbit anti-mouse FITC-conjugated antibodies (Dako) were added in each well. After $1 \mathrm{~h}$ incubation at $37^{\circ} \mathrm{C}$ microplates were rinsed and cell monolayer was examined by UV light microscopy (Zeiss, Axiovert 25).

Virus titration. Titration of IHNV in virus-positive material and in cell culture supernatant was performed in triplicate by end-point dilution on EPC cell cultures in 96-well microplates. The IHNV titre was determined for Samples A1, A2, B1 and B2 stored under different conditions at specific time intervals. The distribution of samples for virus titration in 96-well microplates was performed as described above. The plates were incu- bated at $15^{\circ} \mathrm{C}$ and examined microscopically for cytopathic effect $6 \mathrm{~d}$ post inoculation. The virus titre was than calculated as TCID $_{50} \mathrm{ml}^{-1}$.

RT-PCR and semi-nested RT-PCR. All samples stored under different conditions were tested by RTPCR. When results of the RT-PCR method were negative, semi-nested RT-PCR was performed.

Total RNA was extracted from tested specimens by TRIzol LS reagent (Gibco BRL). Briefly, $250 \mu \mathrm{l}$ of homogenised tissue or cell culture supernatants were mixed with $750 \mu$ TRIzol LS reagent. The extraction procedure followed the manufacturer's instructions and the extracted RNA was dissolved in RNase-free water.

Reverse transcription and PCR amplification of the gene fragment encoding the G-protein was carried out using single step RT-PCR and oligonucleotide primers as described previously (Barlič-Maganja et al. 2002). Additional semi-nested amplification of the obtained products was performed including the same reverse primer as in RT-PCR and an internal forward primer. As a negative control, non-infected cells as well as pools of IHNV-negative fish samples were used. The products of both reactions were analysed by $1.8 \%$ agarose gel electrophoresis.

\section{RESULTS}

Sample A1 stored at $4^{\circ} \mathrm{C}$ and Sample A2 stored at $25^{\circ} \mathrm{C}$ had the initial infectivity $10^{4.8} \mathrm{TCID}_{50} \mathrm{ml}^{-1}$. Virus isolation from Sample A2 was negative after incubating the sample at $25^{\circ} \mathrm{C}$ for more than $1 \mathrm{~d}$. The virus titre in Sample A1 decreased during the first $3 \mathrm{~d}$ and was not detectable on Day 4 by cell culture inoculation (Table 1).

Table 1. Oncorhynchus mykiss. IHNV detection in the fish visceral organ homogenates (Sample A) stored at $4^{\circ} \mathrm{C}$ (Sample A1) and $25^{\circ} \mathrm{C}$ (Sample A2) by virus isolation, RT-PCR and semi-nested RT-PCR. +: positive result; -: negative result (no evidence of virus); ND: not done

\begin{tabular}{|c|c|c|c|c|c|c|}
\hline \multirow{2}{*}{$\begin{array}{l}\text { Time } \\
\text { (d) }\end{array}$} & \multicolumn{2}{|c|}{ Virus isolation $\left(\mathrm{TCID}_{50} \mathrm{ml}^{-1}\right.$ ) } & \multicolumn{2}{|c|}{ RT-PCR } & \multicolumn{2}{|c|}{ Semi-nested RT-PCR } \\
\hline & $\begin{array}{c}\text { Sample A1 } \\
\left(4^{\circ} \mathrm{C}\right)\end{array}$ & $\begin{array}{l}\text { Sample A2 } \\
\left(25^{\circ} \mathrm{C}\right)\end{array}$ & $\begin{array}{c}\text { Sample A1 } \\
\left(4^{\circ} \mathrm{C}\right)\end{array}$ & $\begin{array}{c}\text { Sample A2 } \\
\left(25^{\circ} \mathrm{C}\right)\end{array}$ & $\begin{array}{c}\text { Sample A1 } \\
\left(4^{\circ} \mathrm{C}\right)\end{array}$ & $\begin{array}{c}\text { Sample A2 } \\
\left(25^{\circ} \mathrm{C}\right)\end{array}$ \\
\hline 0 & $10^{4.8}$ & $10^{4.8}$ & + & + & + & + \\
\hline 1 & $10^{3.9}$ & - & ND & + & ND & ND \\
\hline 2 & $10^{2.1}$ & - & + & ND & ND & ND \\
\hline 3 & $10^{0.6}$ & - & ND & + & ND & ND \\
\hline 4 & - & ND & + & + & ND & + \\
\hline 6 & - & ND & ND & - & ND & + \\
\hline 8 & - & ND & ND & - & + & + \\
\hline 13 & ND & ND & + & ND & ND & - \\
\hline 20 & ND & ND & + & ND & + & ND \\
\hline 22 & ND & ND & + & ND & + & ND \\
\hline 35 & ND & ND & - & - & + & ND \\
\hline 54 & ND & ND & - & - & - & - \\
\hline
\end{tabular}


Table 2. Oncorhynchus mykiss. IHNV detection in the cell culture supernatants stored at $4^{\circ} \mathrm{C}$ (Sample B1) and $25^{\circ} \mathrm{C}$ (Sample B2) by virus isolation and RT-PCR test. +: positive result $_{;}-$: negative result (no evidence of virus); ND: not done

\begin{tabular}{|lcccc|}
\hline $\begin{array}{l}\text { Time } \\
(\mathrm{d})\end{array}$ & \multicolumn{2}{c}{$\begin{array}{c}\text { Virus isolation } \\
\left(\mathrm{TCID}_{50} \mathrm{ml}^{-1}\right)\end{array}$} & \multicolumn{2}{c}{ RT-PCR } \\
& $\begin{array}{c}\text { Sample B1 } \\
\left(4^{\circ} \mathrm{C}\right)\end{array}$ & $\begin{array}{c}\text { Sample B2 } \\
\left(25^{\circ} \mathrm{C}\right)\end{array}$ & $\begin{array}{c}\text { Sample B1 } \\
\left(4^{\circ} \mathrm{C}\right)\end{array}$ & $\begin{array}{c}\text { Sample B2 } \\
\left(25^{\circ} \mathrm{C}\right)\end{array}$ \\
\hline 0 & $10^{5.2}$ & $10^{5.2}$ & + & + \\
5 & $10^{5.1}$ & $10^{3.6}$ & ND & ND \\
13 & $10^{5.1}$ & $10^{2.1}$ & ND & ND \\
14 & $10^{4.8}$ & $10^{1.5}$ & ND & ND \\
16 & $10^{4.8}$ & $10^{0.4}$ & + & + \\
18 & $10^{4.7}$ & - & ND & ND \\
30 & $10^{1.2}$ & - & ND & ND \\
34 & $10^{0.4}$ & - & ND & ND \\
36 & $10^{0.2}$ & ND & + & + \\
37 & - & ND & ND & ND \\
49 & - & ND & + & + \\
57 & - & ND & + & + \\
73 & ND & ND & + & + \\
91 & ND & ND & + & + \\
123 & ND & ND & + & + \\
& & & + & + \\
\hline
\end{tabular}

The viral RNA in Sample A1, stored at $4^{\circ} \mathrm{C}$, could be detected by RT-PCR during the experimental period of $22 \mathrm{~d}$ and by semi-nested RT-PCR during a period of 35 d. IHNV RNA in Sample A2, stored at $25^{\circ} \mathrm{C}$, was detected by RT-PCR on Day 4 and by semi-nested RTPCR on Day 8 but not thereafter (Table 1).

With IHNV-infected cell culture medium (Sample B1) stored at $4^{\circ} \mathrm{C}$ the virus titre decreased slowly (Table 2). The IHNV could be detected on cell culture through Day 36. The reduction of virus titre was more drastic in Sample B2. Virus isolation from Sample B2 stored at $25^{\circ} \mathrm{C}$ was possible only through Day 16 . Viral RNA could be detected by RT-PCR throughout the entire experimental period of $123 \mathrm{~d}$ in both samples (Table 2).

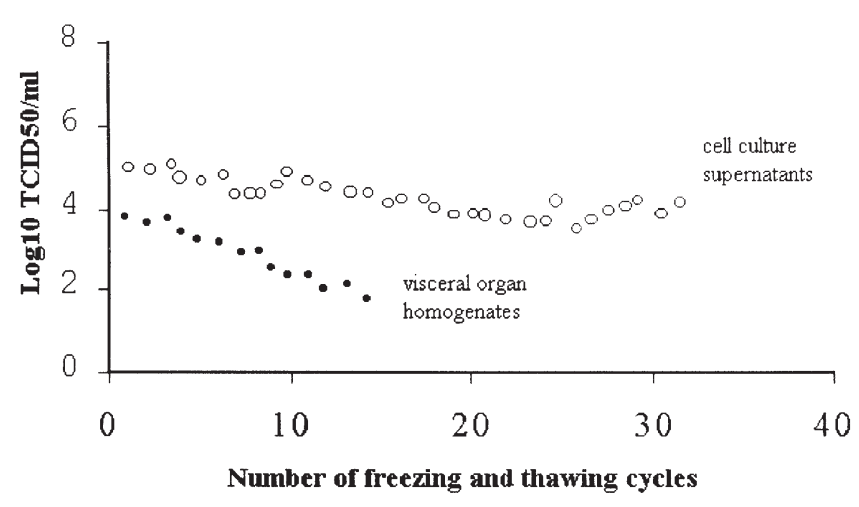

Fig. 1. IHNV in Oncorhynchus mykiss. IHNV titre in the cell culture supernatants and in the visceral organ homogenates measured after each freezing-thawing cycle
The suspension of fish visceral organs and the supernatant fluid from IHNV infected cell culture that were frozen at $-70^{\circ} \mathrm{C}$ were thawed 33 times and virus titre on cell culture was determined. The initial virus titre in the suspension of visceral organs and in the supernatant of cell culture was $10^{4.8}$ and $10^{5.2} \mathrm{TCID}_{50} \mathrm{ml}^{-1}$, respectively. The freezing-thawing procedure had minimal influence on the virus titre in the supernatant of infected cell culture fluid during the whole experiment (Fig. 1). The virus titre in the suspension of visceral organs decreased and, due to the cytotoxic effect, IHNV could not be isolated after 13 freezing-thawing cycles. The molecular methods allowed the detection of viral RNA throughout the experiment (data not shown).

\section{DISCUSSION}

Our laboratory performs virus diagnosis on fish samples coming from different fish farms. Only fresh fish samples are known to be suitable for valid IHNV diagnosis by means of the virus isolation test (Blancou \& Håstein 2000). Specimens, especially from freeranging fish, are sometimes submitted for diagnosis in a decomposed state due to the delay in recovery, storage or dispatch. Using the virus isolation test, only positive results from such samples are valid. When the samples are not transported correctly, or they are stored too long at room temperature, we are unable to isolate IHNV on cell culture. Thermal inactivation and a decrease in IHNV titre within $1 \mathrm{~h}$ at $27^{\circ} \mathrm{C}$ has already been reported (Gosting \& Gould 1981).

The objective of our study was to evaluate the usefulness of RT-PCR followed by semi-nested RT-PCR for the detection of IHNV in fish samples stored under different conditions. The efficiency and sensitivity of molecular detection methods were compared with the cell culture isolation method from clinical samples and from supernatants of infected cell culture.

In previous studies of IHNV detection by molecular methods, conditions were optimised and the methods were suggested as a rapid alternative method to the virus isolation method (Barli-Maganja et al. 2002). For virus detection in visceral organs of IHNV-infected fish, the virus isolation test, RT-PCR and semi-nested RT-PCR methods were compared. Molecular methods were found to be as sensitive as virus isolation on cell culture. The virus from freshly obtained fish samples (pooled visceral organs) stored at $4^{\circ} \mathrm{C}$ could be detected for a period of $3 \mathrm{~d}$, while the same samples stored at $25^{\circ} \mathrm{C}$ were positive in the virus isolation test for only $24 \mathrm{~h}$ (Table 1). It has already been reported that the retention of viral infectivity in different fish samples is greatly dependent upon the storage temperature and the length of storage time (Burke \& Mulcahy 1983). In visceral 
organs, like spleen and kidney, the initial infectivity dropped after $4 \mathrm{~h}$ at room temperature and the virus could not be isolated from samples stored at room temperature for $2 \mathrm{~d}$. After storage at $4^{\circ} \mathrm{C}$ for $3 \mathrm{~d}$ the virus titre in spleen and kidney considerably decreased and the virus could not be isolated from kidney after $1 \mathrm{wk}$ or from spleen after $4 \mathrm{wk}$. Bacteria and fungi-free IHNVinfected cell culture supernatants stored at $4^{\circ} \mathrm{C}$ were positive in the virus isolation test for 36 and $16 \mathrm{~d}$ when stored at $25^{\circ} \mathrm{C}$ (Table 2). The IHNV titre decreased rapidly in samples stored at $25^{\circ} \mathrm{C}$ but slowly in samples stored at $4^{\circ} \mathrm{C}$. This observation may indicate that other factors such as neutralising antibodies or cellular enzymes can inactivate virus in tissue samples.

To detect IHNV in fish samples stored under different conditions for longer periods of time, molecular methods were confirmed to be more effective and sensitive. Viral RNA could be detected in visceral organ samples stored at $25^{\circ} \mathrm{C}$ for $8 \mathrm{~d}$ and in samples stored at $4^{\circ} \mathrm{C}$ for $35 \mathrm{~d}$ (Table 1). The antigen-antibody complexes that might produce lower virus titre or negative results in virus isolation tests do not influence the detection of viral RNA by RT-PCR. It was also indicated that sample contamination with fungi and bacteria had less influence on the RT-PCR results. To avoid false negative RTPCR results due to the presence of inhibitors, additional internal controls for the amplification of RNA should be included in the test (Smith et al. 2000).

The effect of intracellular enzymes, released during the freezing and thawing procedures, on the IHNV infectivity was examined. After 33 freezing-thawing cycles, maintenance of IHNV titre in cell culture suspension, but reduction of virus titre in fish organ suspension, was observed (Fig. 1).

Rapid and sensitive diagnostic methods are critical for timely and correct diagnosis. The storage conditions of samples are very important for effective accurate diagnostic methods. The virus isolation method for IHNV detection is reliable only when fresh fish samples stored at $4^{\circ} \mathrm{C}$ are used for the diagnosis. When it is not possible to inoculate cell culture within $48 \mathrm{~h}$ after the collection of the tissue material, homogenised filter sterilised tissue supernatants have to be prepared and stored in frozen conditions. For samples for which storage conditions are unknown, examination using molecular methods is recommended. RT-PCR has been shown here to provide better sensitivity and reliability, as compared to the virus isolation test, when used to detect IHNV in decomposed tissue material.

Acknowledgements. Dr. Guiseppe Bovo, Istituto Zooprofilattico Sperimentale delle Venezie, Padova, Italy is deeply acknowledged for contributing reference strain IHNV 4008. This research was founded by the Ministry of Education, Science and Sport and by the Ministry of Agriculture, Forestry and Food of Slovenia.

\section{LITERATURE CITED}

Alonso M, Rodríguez S, Pérez Prieto SI (1999) Nested PCR improves detection of infectious hematopoietic necrosis virus in cells coinfected with infectious pancreatic necrosis virus. J Virol Methods 81:1-9

Arakawa CK, Deering RE, Higman KH, Oshima KH, O'Hara PJ, Winton JR (1990) Polymerase chain reaction (PCR) amplification of a nucleoprotein gene sequence of infectious hematopoietic necrosis virus. Dis Aquat Org 8: 165-170

Barlič-Maganja D, Štrancar M, Hostnik P, Jenčič V, Grom J (2002) Comparison of the efficiency and sensitivity of virus isolation and molecular methods for routine diagnosis of infectious haematopoietic necrosis virus and infectious pancreatic necrosis virus. J Fish Dis 25:73-80

Baudin-Laurencin F (1987) IHN in France. Bull Eur Assoc Fish Pathol 7:104

Blancou J, Håstein T (eds) (2000) OIE diagnostic manual for aquatic animal diseases, 3rd edn. Office International des Epizooties, Paris

Bovo G, Giorgetti G, Jørgensen PEV, Olesen NJ (1987) Infectious haematopoietic necrosis: first detection in Italy. Bull Eur Assoc Fish Pathol 7:124

Bruchhof B, Marquardt O, Enzmann PJ (1995) Differential diagnosis of fish pathogenic rhabdoviruses by reverse transcriptase-dependent polymerase chain reaction. J Virol Methods 55:111-119

Burke J, Mulcahy D (1983) Retention of infectious haematopoietic necrosis virus infectivity in fish tissue homogenates and fluids stored at three temperatures. J Fish Dis 6: $543-547$

Dixon PF, Hill BJ (1984) Rapid detection of fish rhabdoviruses by the enzyme-linked immunosorbent assay (ELISA) Aquaculture 42:1-12

Enzmann PJ, Benger G, Bruchhof B, Hoffmeister K (1991) Cross-reactions between VHS-V and IHN-V detected by polyclonal immune sera and monoclonal antibodies. In: Book of Abstracts. Diseases of fish and shellfish. Fifth International Conference of the EAFP, Budapest, p 36

Gosting LH, Gould RW (1981) Thermal inactivation of infectious hematopoietic necrosis and infectious pancreatic necrosis viruses. Appl Environ Microbiol 41:1081-1082

Jenčič V, Hostnik P (1998) The spreading of salmonid viral diseases in Slovenia. Vet Nov 24:285-289

Kurath G, Leong JC (1985) Characterization of infectious hematopoietic necrosis virus mRNA species reveals a nonvirion rhabdovirus protein. J Virol 53:462-468

Kurath G, Ahern KG, Pearson GD, Leong JC (1985) Molecular cloning of the six mRNA species of infectious hematopoietic necrosis virus, a fish rhabdovirus, and gene order determination by R-loop mapping. J Virol 53:469-476

Lorenzen E, Carstensen B, Olesen NJ (1999) Inter-laboratory comparison of cell lines for susceptibility to three viruses: VHSV, IHNV and IPNV. Dis Aquat Org 37:81-88

Miller TA, Rapp J, Wastlhuber U, Hoffmann RW, Enzmann PJ (1998) Rapid and sensitive reverse transcriptase-polymerase chain reaction based detection and differential diagnosis of fish pathogenic rhabdoviruses in organ samples and cultured cells. Dis Aquat Org 34:13-20

Pietsch JP, Amend DF, Miller CM (1977) Survival of infectious hematopoietic necrosis virus held under various conditions. J Fish Res Board Can 34:1360-1364

Ristow SS, Arnzen JM (1989) Development of monoclonal antibodies that recognize a type-2 specific and common epitope on the nucleoprotein of infectious hematopoietic necrosis virus. J Aquat Anim Health 1:119-125 
Ristow SS, Arnzen JM (1991) Monoclonal antibodies to the glycoprotein and nucleoprotein of infectious hematopoietic necrosis virus (IHNV) reveal differences among isolates of the virus by fluorescence, neutralization and electrophoresis. Dis Aquat Org 11:105-115

Sanz F, Coll J (1992) Techniques for diagnosing viral diseases of salmonid fish. Dis Aquat Org 13:211-223

Smith J, McElhinney LM, Heaton PR, Black EM, Lowings JP

Editorial responsibility: Jo-Ann Leong,

Corvallis, Oregon, USA
(2000) Assessment of template quality by the incorporation of an internal control into a RT-PCR for the detection of rabies and rabies-related viruses. J Virol Methods 84:107-115

Walker PJ, Benmansour A, Dietzgen R, Fang RX and 6 others (2000) Family Rhabdoviridae. In: van Regenmortel MHV, Fauquet CM, Bishop DHL (eds) Virus taxonomy, Seventh Report of the International Committee for Taxonomy of Viruses. Academic Press, San Diego, CA, p 563-583

Submitted: February 13, 2002; Accepted: June 25, 2002 Proofs received from author(s): November 8, 2002 